\title{
Fire ecology of a Late Carboniferous floodplain, Joggins, Nova Scotia
}

\author{
H. J. FALCON-LANG \\ Department of Geology, Royal Holloway, University of London, Egham, Surrey TW20 0EX, UK \\ (e-mail: falconlang@gl.rhbnc.ac.uk)
}

\begin{abstract}
The facies distribution and palaeobotanical identity of fossil charcoal is described from the Upper Carboniferous (Westphalian A-B) Joggins section, Nova Scotia, in order to examine the fire ecology of early Westphalian floodplains. Three charcoal assemblages are noted. Assemblage (1) consists of channel sandstone bodies, containing beds of calcrete breccia, cordaite logs (up to $3 \mathrm{~m} \mathrm{long}$ ), and coniferopsid wood charcoal. This assemblage records upland coniferopsid forest fires which altered basin hydrology and promoted flooding in downstream floodplain rivers. Assemblage (2) consists of thin (1-8 $\mathrm{mm}$ thick) coals containing hollow, sigillarian tree stumps and lepidodendrid and medullosan plant compressions. Fifteen of the 29 stumps observed have a $2-5 \mathrm{~cm}$ thick basal layer infilling the stumps, composed entirely of sigillarian charcoal. Sigillarian and medullosan charcoal is also scattered around the outside of these stumps. This assemblage represents fire in lowland peat-forming communities dominated by Sigillaria and medullosan pteridosperms. These forest fire profiles were slowly buried in floodplain muds. Assemblage (3) consists of a heterolithic sheet sandstone body containing a $2.5 \mathrm{~m}$ high sigillarian tree trunk with an internal, basal trunk deposit of sigillarian charcoal and a lightly charred bark rind. This also records fire in lowland sigillarian forests, but, in contrast to (2), this forest fire profile was buried rapidly in a distributary lobe.
\end{abstract}

Keywords: Carboniferous, Westphalian, Lycopsida, charcoal, fires.

Although natural, lightning-initiated fires are uncommon in the everwet tropics, in settings with only a slight rainfall seasonality, fires can be frequent, exerting an important influence on ecosystems (Goldammer 1993). When fires do occur in everwet systems (e.g. SE Asian fires of 1982-83 and 1997-98) they are usually associated with exceptional, short-term climatic excursions (e.g. El Ninõ) and have catastrophic effects on regional vegetation (Johnson 1984; Goldammer \& Seibert 1990). In contrast, in seasonal tropical environments fires may occur annually and many plant communities have evolved an array of 'adaptive traits' that allow them to tolerate such disturbances (Goldammer 1993).

In addition to the destructive effects on vegetation, fires also can influence the regional physical environment. For instance, where fires burn down into lowland peat deposits, freshwater ponds may replace mire vegetation (Cypert 1972). Alternatively, if fires burn levée vegetation, fire splays may be formed (Staub \& Cohen 1979; Stanistreet et al. 1993). Fires also can promote flooding by markedly reducing the capacity of a catchment to absorb water (Johnson 1984), and if fires destroy crucial slope-stabilising vegetation, debris flows and massively increased sediment transport may result, profoundly influencing alluvial morphology (Swanson 1981; Meyer et al. 1992; Meyer \& Wells 1997).

The occurrence of fires in the geological past can be recognized by the presence of fossil charcoal, the inert product of incomplete combustion (Browne 1958), incorporated into sedimentary rocks. Many early workers called this substance fusain and came to conflicting conclusions about its origin (see Scott 1989 for a review). However, recent chemical and physical studies have demonstrated unequivocally that fusain represents fossil charcoal (Scott 1989; Jones \& Chaloner 1991).

Although charcoal is particularly abundant in the Upper Carboniferous coal measures of Europe and North America (Robinson et al. 1997), there has only been a passing consid- eration of the role played by fire in the densely vegetated tropical floodplains that formed these deposits (Scott 1979; DiMichele \& Phillips 1994; Scott \& Jones 1994). Little is understood about which plant communities were prone to fire and what effects these disturbances had on ecosystems and biota. It is not known whether most charcoal was sourced from extra-basinal fires or represents local input. Nor has it been demonstrated whether fires induced flooding and debris flows, as in present fluvial systems. In this study charcoal is examined from the classic Upper Carboniferous Joggins section, Nova Scotia (Gibling 1987) in order to resolve some of these questions.

\section{Study area}

The Joggins section is a $1400 \mathrm{~m}$ thick sequence of Upper Carboniferous strata excellently exposed for $6 \mathrm{~km}$ on the Bay of Fundy, Nova Scotia (Fig. 1a). Between Lower Cove and Ragged Reef, strata dip at $21^{\circ} \mathrm{SW}$ and comprise the Joggins and Springhill Mines formations (Fig. 1b) of the Cumberland Group and span the Westphalian A-B (Gibling 1995). This Joggins section is particularly famous for the early reptile remains found within upright lepidodendrid tree trunks by Charles Lyell (Lyell \& Dawson 1853; Carroll 1964; Scott 1998).

The sequence was deposited in a near equatorial floodplain/ mire environment (Gibling 1987; Scotese \& McKerrow 1990) with sediment sourced from uplands to the north and northwest (Gibling et al. 1992). Lower horizons in the sequence record the development of a variety of alluvial geometries ranging from anastomosing to meandering (Calder 1994), whilst the section between MacCarron's Creek and Ragged Reef (Fig. 1b) is interpreted as entirely representing anastomosing channel deposition (Rust et al. 1984). Originally 


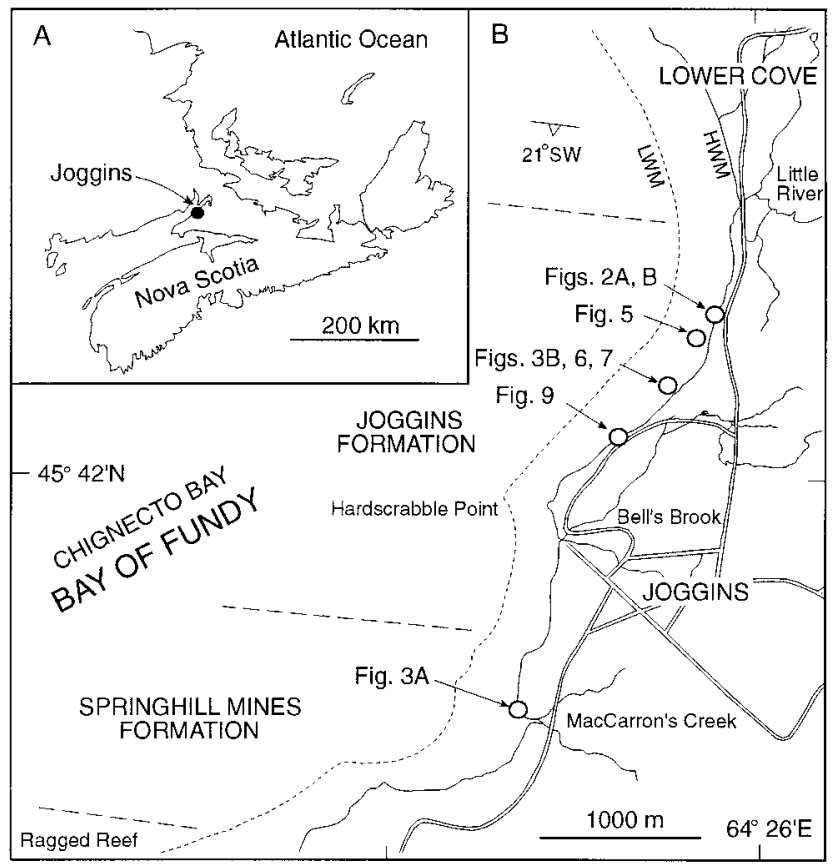

Fig. 1. (a) Location of Joggins section, Nova Scotia. (b) Map of Joggins section showing stratigraphic units and position of study areas (after Gibling 1987; Ryan \& Boehner 1993).

thought to have occupied an intermontane basin, recent work has identified intermittent estuarine incursions within the lower part of the sequence (Archer et al. 1995). The regional climate is believed to have been seasonally humid (Calder \& Gibling 1994).

Charcoal is abundant throughout the section (Dawson 1868) and records multiple fire events. In order to assess the role of wildfire in this Upper Carboniferous floodplain, the facies distribution and botanical identity of charcoal has been examined and is described below.

\section{Facies analysis}

\section{Facies 1a: channelized sandstone body, Type A}

Facies 1a is the dominant type of channel sandstone body in the Joggins Formation. It is characterized by the unit shown in Fig. 2a, which occurs within a red mudstone sequence (Facies 2c). This unit is a 4-7 m thick, fine to medium grained sandstone composed of 17 erosive-based U-shaped channel bodies. Individual channel bodies are 1-2.5 m deep, 10-20 m wide and contain basal groove casts oriented N-S, and occasional cross-bedded units that indicate southerly palaeoflow. Sometimes the tops of the channel sandstone bodies overstep the channel margins and grade laterally into sheet sandstone units ('wings'; Friend et al. 1979). The fill of individual channels is rather variable and three characteristic channel subfacies have been identified (Fig. 2a).

Subfacies A. This is the most common channel fill type (Fig. 2b) consisting of a massive, fine-grained sandstone lacking internal architecture except for occasional low-angle erosive surfaces and rare cross-beds. The base of the channel fill is dominated by large $(10-20 \mathrm{~cm})$ Calamites compressions or more rarely by a thin $(5 \mathrm{~cm})$ basal lag containing mudstone and calcrete clasts. Bedding is undulose towards the top, and beds show a slight upward fining.
Subfacies B. This channel fill type consists of laminated green and red mudstone/siltstone units, together with laminated fine-grained sandstone units containing rare trough cross-bedding. Mudstone clasts and unfragmented plant material, including compressions of Calamites and Cordaites, are present.

Subfacies C. This is a multi-storey channel fill sequence composed of heterolithic, erosive-based packages (Fig. 2b). Some packages consist of trough cross-bedded sandstone containing abundant mudstone clasts. Other packages are composed of thick $(50 \mathrm{~cm})$, sulphurous, chaotically bedded, medium-grained sandstone containing abundant unidentified coalified logs (1 m long), Cordaites, Artisia and Calamites (both as compressions and pith casts). Still further packages consist largely of a calcrete breccia. Charcoal is always present in this subfacies; it consists of $1-3 \mathrm{~cm}$ fragments of Dadoxylontype coniferopsid wood and rare, $10 \mathrm{~cm}$ long, partially charred fragments of Artisia (Falcon-Lang 1998a).

\section{Facies 1b: channelized sandstone body, Type B}

This facies is characterized by the sandstone unit at $12-13 \mathrm{~m}$ in Fig. 3a. The upper surface of this unit exhibits 'ridge and swale topography' (RST) with a gently curved strike trending NWSE. Lower beds are dominated by trough cross-bedding and ripple cross-lamination with SE palaeocurrents parallel to the strike of the RST. At several horizons, abundant, closely spaced casts of in situ Calamites stems occur (up to 13 stems $\mathrm{m}^{-2}$ ) associated with highly fragmented Asterophyllites. Towards the upper surface of the sandstone unit, three large (49 cm diameter, $>2.8 \mathrm{~m}$ long), anatomically preserved cordaite logs (Fig. 4a) are present aligned parallel to the strike of the RST, together with large ( $25 \mathrm{~cm}$ long) unfragmented Cordaites leaves (Fig. 4c).

\section{Facies 1c: channelized sandstone body, Type C}

This facies, which only occurs once in the Joggins section, is characterized by the unit at $13-15 \mathrm{~m}$ in Fig. 3a. It is composed of a medium to coarse grained, poorly sorted, sandstone organized into broad, shallow, erosive-based channel structures ( $>8 \mathrm{~m}$ wide, $1 \mathrm{~m}$ deep). Mudstone, siderite and calcrete intraclasts are abundant, composing locally up to $70 \%$ of the total sediment. Rarely, small (1-2 m wide, $1 \mathrm{~m}$ deep), E-W trending channels composed of unstructured medium-grained sandstone are present, cutting into the underlying rubbly beds. Plant material is extremely abundant throughout Facies 1c, particularly at the base. The most common plant fossils are cordaite logs ( $>2 \mathrm{~m}$ long), Artisia pith casts (>20 cm long, Fig. $4 \mathrm{~b}$ ), Calamites pith casts and compressions and rare sigillarian trunk compressions. Charcoal is also abundant consisting mainly of $1-5 \mathrm{~cm}$, slightly rounded fragments of Dadoxylontype coniferopsid wood. Other charred wood fragments present are similar to those described by Galtier et al. (1992) and are attributed with reservation to early conifers (Fig. $5 \mathrm{a}-\mathrm{c})$.

\section{Facies 2a: green mudstone units}

These are poorly laminated green mudstone units which contain common fossil plant fragments (Fig. 3b). Plant assemblages are dominated by Lepidodendron, Lepidophloios and Sigillaria axes (up to $10 \mathrm{~cm}$ diameter) and detached 


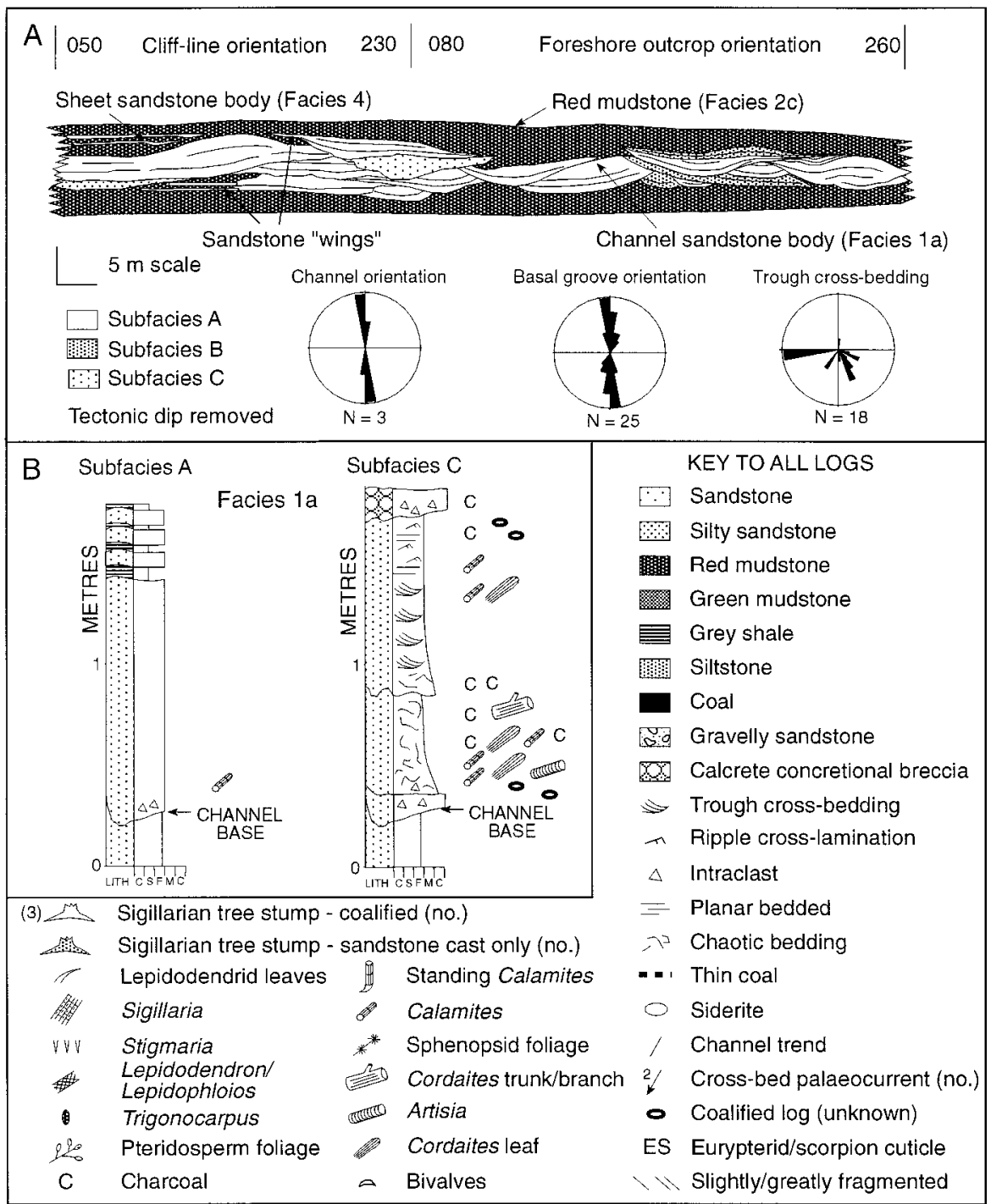

Fig. 2. (a) Alluvial architecture of Facies 1a. (b) Graphic Logs of Facies 1a (Subfacies A and C). lepidodendrid leaves. Also present in smaller quantities are: Calamites, Asterophyllites, Annularia, pteridosperm axes (5$20 \mathrm{~mm}$ diameter), Alethopteris, Neuropteris, Sphenopteris, Trigonocarpus and Cordaites. Stigmaria and Pinnularia occur locally. Large (20 cm diameter) siderite nodules are common and contain anatomically preserved pteridosperm rootlets. Rare beds within the green mudstone units consist of $5-15 \mathrm{~cm}$ thick, well laminated, laterally discontinuous, mediumgrey shales within shallow $(15 \mathrm{~cm}$ deep) depressions. These contain abundant fragments of scorpion and eurypterid cuticle (Stankiewicz et al. 1998), and common bivalves.

\section{Facies 2b: thin coals}

At many intervals, exclusively associated with Facies 2a, thin (1-8 mm thick) mudstone-rich coals occur. In laterally extensive wave-cut platform exposures, these coals contain numerous (29 observed), closely spaced in situ lepidodendrid stumps (24-131 cm diameter, 5-15 cm high); some of these exhibit attached Stigmaria (Fig. 6). All these stumps are hollow, and consist of a 5-20 mm thick, coaly bark rind surrounding a green mudstone fill. Bark rinds lack a primary surface with leaf scars making taxonomic assignment difficult. However, the rinds of some stumps are calcareously permineralized and contain anatomically preserved, banded periderm suggestive of Sigillaria (Eggert 1961). A monotypic assemblage of the sigillarian megaspore Tuberculatisporites within Facies 2b further points to the sigillarian identity of these lepidodendrid stumps (Fig. 4e). Also present in Facies $2 \mathrm{~b}$ are compressions of large (40 cm diameter), prone sigillarian trunks together with partially fragmented pteridosperm axes, medullosan resin rodlets, Alethopteris, Calamites, Asterophyllites, Sphenophyllum and Cordaites. Rare horizons solely contain Cordaites.

Within the hollowed base of 15 of the sigillarian stumps a layer of charcoal ( $2-5 \mathrm{~cm}$ thick) occurs. This 'charcoal mat' is totally composed of detrital charcoal fragments crushed together into a single block, with no interstitial sediment (Figs $5 \mathrm{~d}, 7)$. The basal 2-5 mm of the charcoal mat consists of highly crushed parenchymous tissue, whilst the upper part is largely dominated by centimetre-sized blocks of periderm exhibiting very thick radial cell walls (Fig. 5f). The presence of rhythmic bands of secretory ducts suggests that this is sigillarian periderm.

The standard reflectance of charcoal fragments was measured in one charcoal mat (method outlined in Jones et al. 1991) and a marked and systematic decrease in reflectance was 


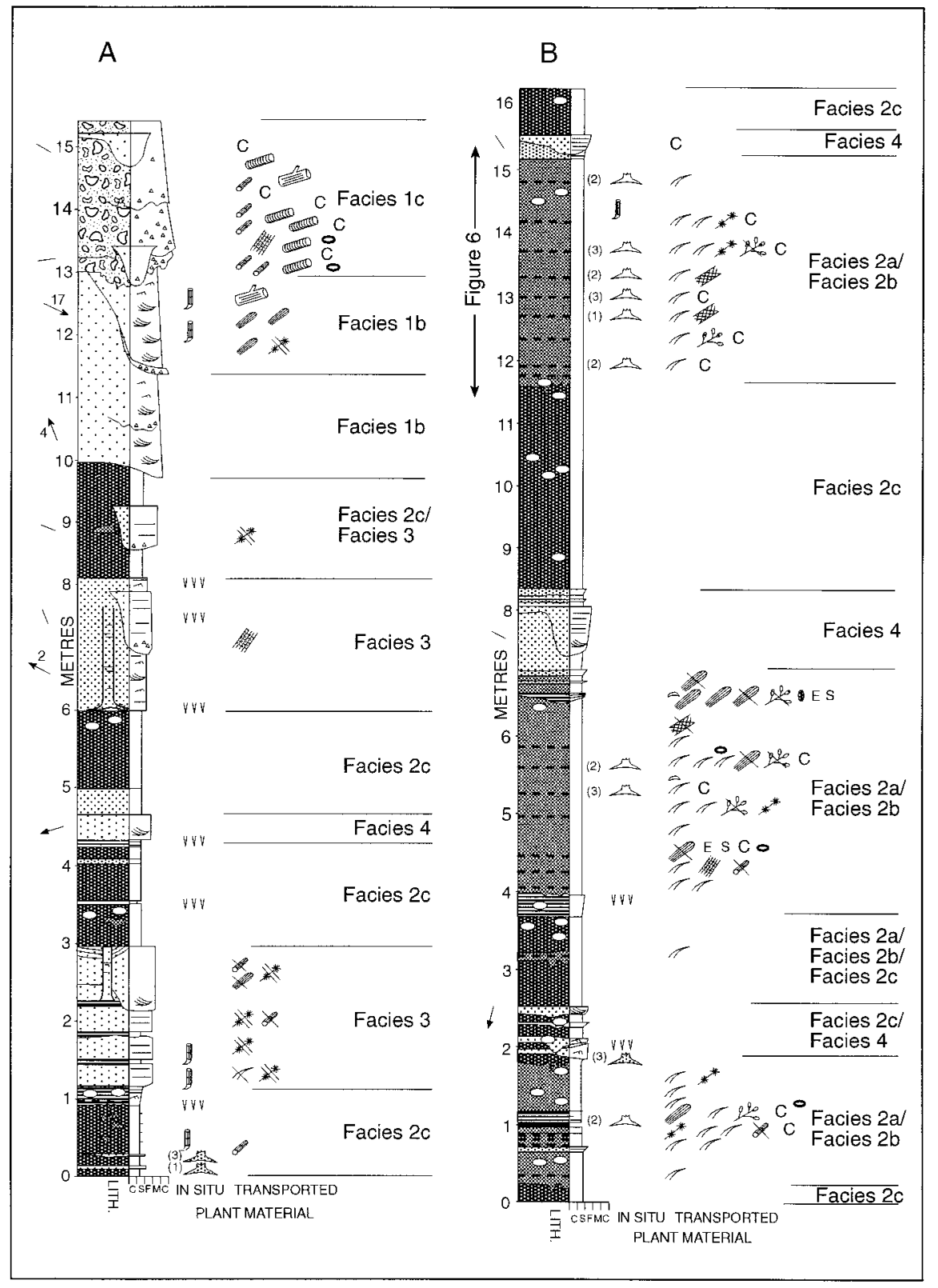

Fig. 3. (a) Graphic log of outcrop at MacCarron's Creek. (b) Graphic log of Lower Cove Section. See Fig. 2 for key and Fig. $1 \mathrm{~b}$ for location of logs. found from the base to the top (Fig. 8a). As Jones et al. (1991) demonstrated a linear relationship between charcoal reflectance and charring temperature, these results imply that fragments up through the charcoal mat are progressively less charred. This interpretation was supported by measuring the length : breadth ratios of periderm fragments at the top and base of the charcoal mat (Fig. 8b). Basal periderm fragments were found to be approximately equant $(1-2 \mathrm{~cm})$, as is typical of well charred material, whilst charcoal from the top of the mat consisted of elongate fragments up to $10 \mathrm{~cm}$ long, as is typical of partially charred material (Scott 1989). Blocks (1-3 cm in size) of sigillarian periderm are also present outside the stumps, scattered within the coal, in a dense layer (42-96\% charcoal by surface cover) distributed around the stumps. These charcoal layers extend up to $1-3 \mathrm{~m}$ from stumps and are often covered by a thin $(2 \mathrm{~mm})$ calcite layer (Fig. 7). The charcoal itself is frequently permineralized by calcite.
Mesoscopic $(0.2-2 \mathrm{~mm})$ charcoal particles are also present within the thin coals. Most abundant are charred fragments of lepidodendrid leaves and manoxylic medullosan wood. Charred fragments of Dadoxylon-type coniferopsid wood, branching lyginopterid rachises (Fig. 5e), Cordaites felicis Benson (Good \& Taylor 1970), and Sphenophyllum also rarely occur.

\section{Facies 2c: red mudstone units}

These are unlaminated red mudstone units that entirely lack coalified plant material (Fig. 3B). Lepidodendrid stump casts are occasionally present but no coaly bark rind is ever preserved. Large $(20 \mathrm{~cm})$ nodules of siderite occur abundantly, some casting Stigmaria. The contact between the red mudstone and green mudstone units (Facies 2a) is gradational, occurring over a thickness of around $5 \mathrm{~cm}$. In the Joggins Formation, red 

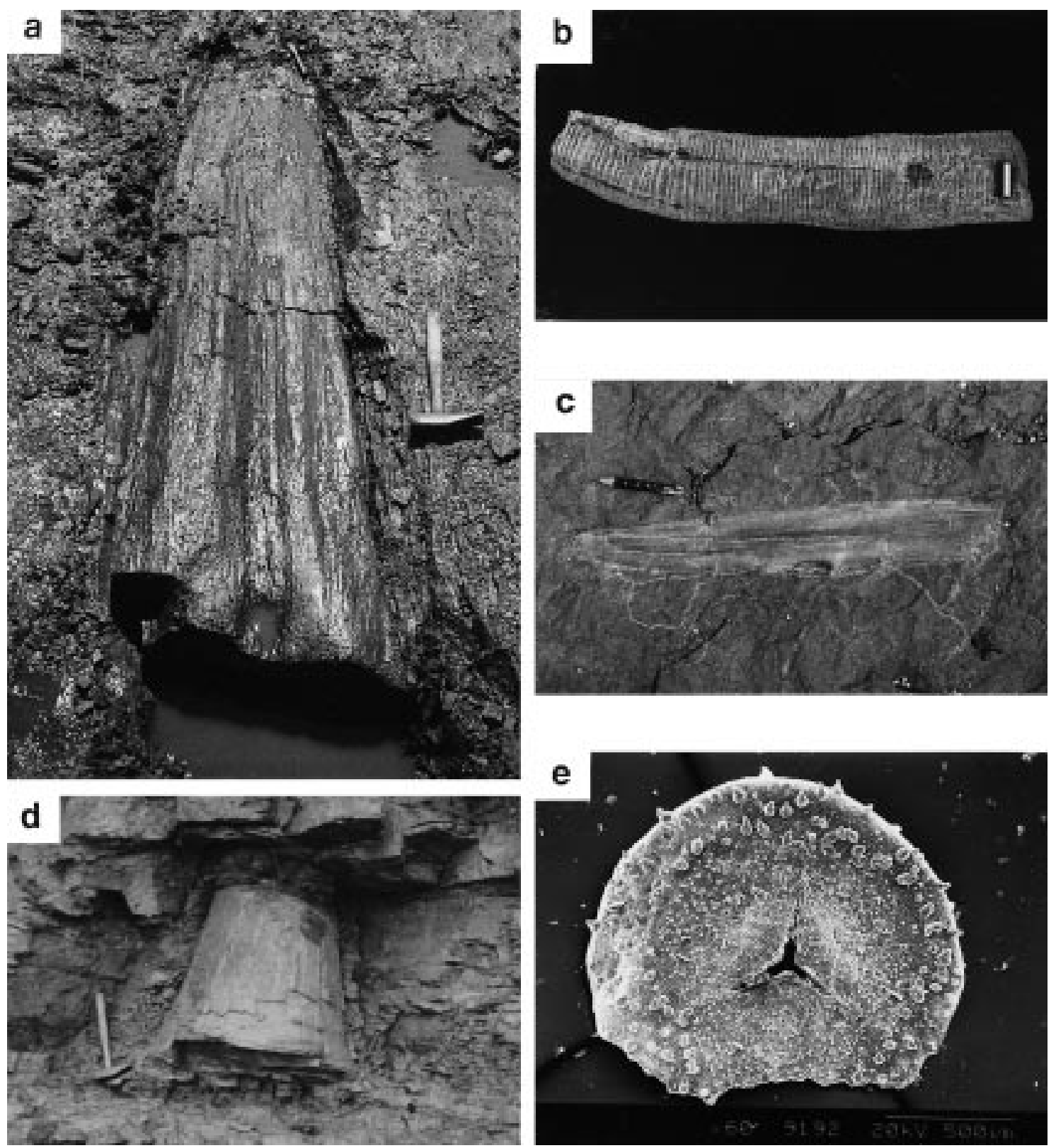

Fig. 4. Macro-plant fossils. (a) Prone cordaite trunk, Facies $1 \mathrm{~b}$, Hammer is $30 \mathrm{~cm}$ long. (b) Sandstone cast Artisia, Facies $1 \mathrm{c}$, Scale bar is $1 \mathrm{~cm}$. (c) $25 \mathrm{~cm}$ long Cordaites leaf, Facies 1b. (d) Sandstone cast of a sigillarian trunk, Facies 3, Hammer is $30 \mathrm{~cm}$ long. (e) Tuberculatisporites, a sigillarian megaspore, Facies 2b (SEM).

and green mudstone units are present in roughly equal proportions; however, in the Springhill Mines Formation, green intervals are largely absent and unbroken sequences of red mudstone occur.

\section{Facies 3: heterolithic silty-sandstone sheets}

This facies consists of up to $3 \mathrm{~m}$ thick units composed of thinly bedded, fine-grained silty sandstone and grey siltstone (Fig. 3a). Sandstone beds are usually lenticular or planar and commonly locally contain current ripple cross-lamination. Siderite nodules $(2-10 \mathrm{~cm})$ are common. Small channelized sandstone bodies (up to $1 \mathrm{~m}$ deep, $2 \mathrm{~m}$ wide) occasionally cut into these heterolithic units. These contain planar lamination or trough cross-bedding.
Large, in situ lepidodendrid tree trunks (up to $3.2 \mathrm{~m}$ high) are often present, rooted in grey mudstone or coal beds beneath this facies. These trunks have thick $(5-10 \mathrm{~mm})$, coaly bark rinds with a prominent vertical ribbing suggestive of Sigillaria (Fig. 4d), and occasionally possess attached Stigmaria. Trunks are infilled with horizontally laminated, siltstone-sandstone beds. Centroclinal cross-stratification (Underwood \& Lambert 1974) is sometimes associated with the exterior of these tree trunks. One upright Sigillaria examined exhibited a siltstone deposit (20 cm thick) within the trunk base containing common charred fragments of sigillarian periderm. It was also observed that the bark rind of this individual tree was charred on the inside of the trunk, above a height of $1.5 \mathrm{~m}$ over the trunk base (Fig. 9). In situ Calamites stems (up to $80 \mathrm{~cm}$ high), preserved as pith casts, are also 

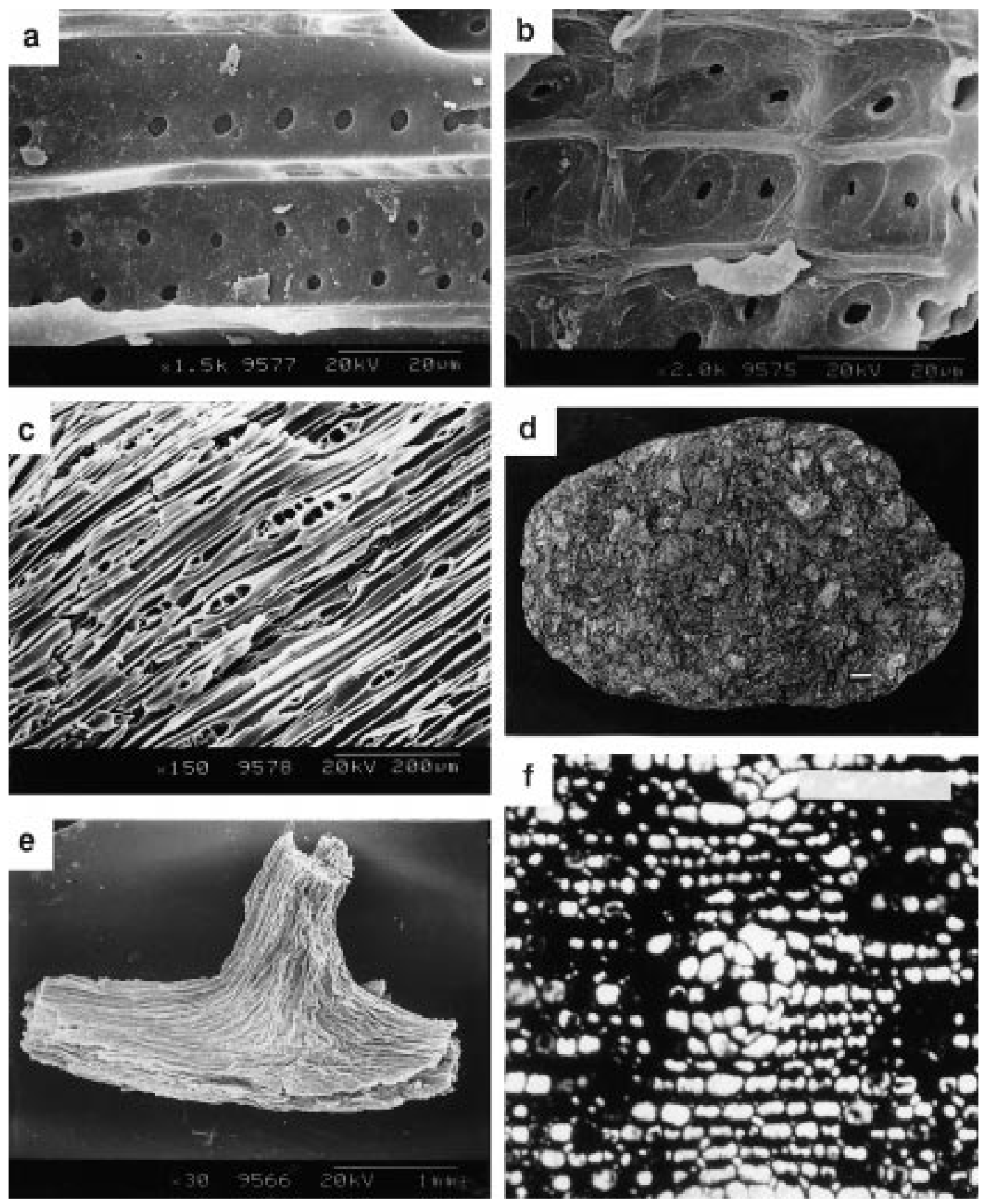

Fig. 5. Charcoal. (a-c) Coniferopsid wood charcoal, attributed with reservation to early conifers, Facies 1 c. (a) Uniserial/biserial pitted tracheids, radial view. (b) Araucaroid cross-field pitting, radial view. (c) Uniseriate rays, tangential view. (d-f) Facies 2 b. (d) Charcoal mat. Removed from sigillarian stump illustrated in Fig. 7. Basal surface is shown. Square blocks are periderm charcoal. Rounding of sample, partly due to wave abrasion on foreshore, scale bar $1 \mathrm{~cm}$. (e) Branching lyginopterid rachis. (f) Sigillarian periderm charcoal, scale bar is $200 \mu \mathrm{m}$ (thin section). All SEMs except (d) and (f).

present in this facies, rooted at several horizons. Partially fragmented compressions of Lepidodendron, Lepidophloios, Sigillaria and Stigmaria occur rarely throughout.

Facies 4: sheet sandstone units with wavy laminations

Facies 4 occurs very commonly in the Joggins section and consists of $0.1-1 \mathrm{~m}$ thick sheet sandstone units with a wavy lamination and gradational tops and bases. The sheet sandstone units locally contain climbing ripple cross-lamination and highly fragmented plant debris (mainly Calamites). In situ sandstone casts of lepidodendrid trunks, rooted in underlying mudstone beds are common. The sheet sandstone units are occasionally cut into by narrow, steep-sided channel sandstone bodies (1 $\mathrm{m}$ deep, $1-2 \mathrm{~m}$ wide) that contain planar or trough cross-bedding. Isolated blocks $(1-3 \mathrm{~cm})$ of charcoal are present 


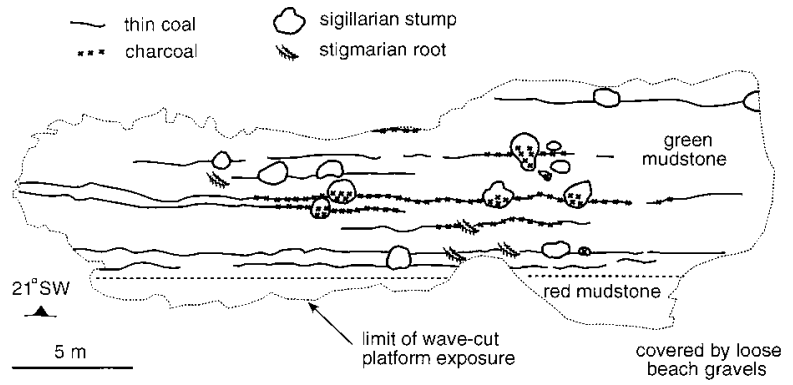

Fig. 6. Plan view of foreshore outcrop showing nine successive sigillarian forest profiles exposed in oblique cross-section (Facies $2 \mathrm{a}-\mathrm{b})$. See Figs $1 \mathrm{~b} \& 3 \mathrm{~b}$ for location details.

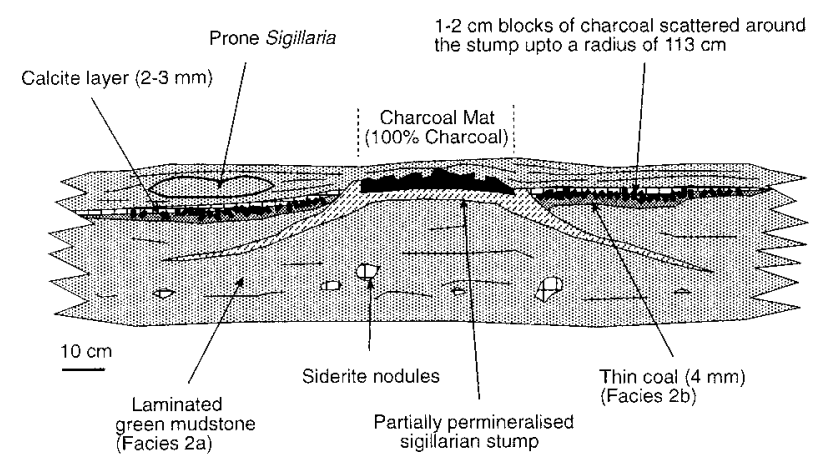

Fig. 7. Detailed sketch of a sigillarian stump associated with charcoal in Facies 2b. See Fig. 1b for location details.

A

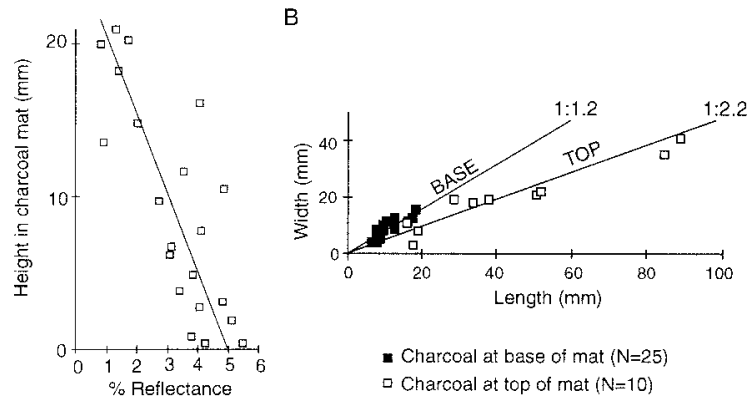

Fig. 8. (a) Percentage reflectance of fragments of sigillarian periderm charcoal up through the charcoal mat. (b) Length:width ratios of sigillarian periderm charcoal at top and base of the charcoal mat.

locally, composed in approximately equal proportions of sigillarian periderm and Dadoxylon-type coniferopsid wood.

\section{Sedimentary environments and plant ecology}

\section{Facies 1a: anastomosing or low sinuosity channels}

Facies 1a represents the deposits of small, narrow river channels, incised into red floodplain muds during periods of high discharge. The unstructured nature of most channel fills (Subfacies A) indicates that vertical accretion was the dominant channel process (Smith 1986). Sandstone 'wings' at the top of a few Subfacies A deposits may record periods of high discharge when flow overtopped the channel margins and deposited sands on the overbank environment (Friend et al. 1986). Siltstone-dominated channel deposits (Subfacies B)

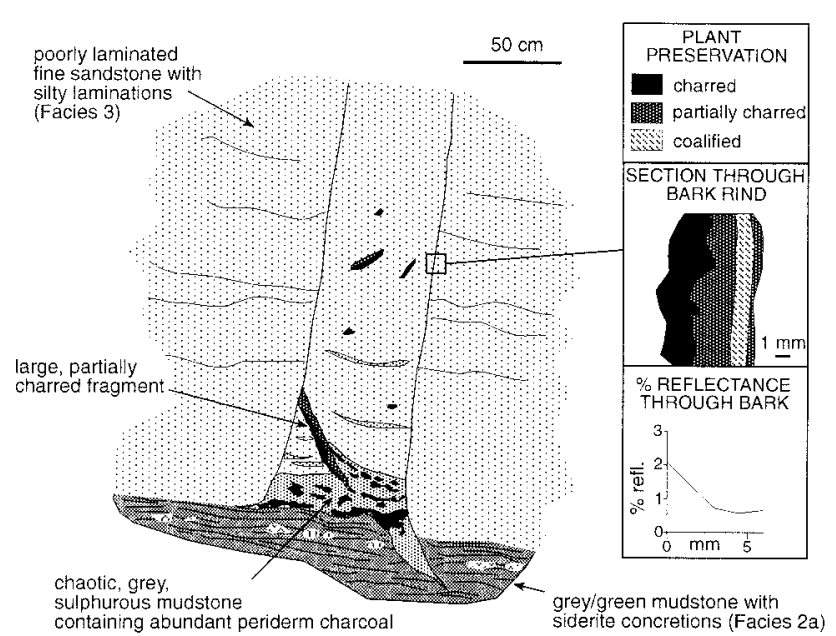

Fig. 9. Upright sigillarian sandstone trunk cast with partially charred bark rind in Facies 3. See Fig. 1b for location details.

were probably formed during channel abandonment (Stanistreet et al. 1993). Heterolithic channel deposits (Subfacies C), however, composed of cross-bedded units of sandstone and breccia, were probably formed by irregular pulses of very high discharge. Thick beds of allochthonous calcrete breccia imply that sediment was primarily sourced from welldrained regions upstream (Goudie 1983) rather than from lowland swamps, and that these regions were experiencing severe denudation.

Facies 1a appears to have formed in a channel network experiencing rather irregular discharge conditions. In this tropical Carboniferous setting irregular alluvial discharge might have been generated by a monsoonal seasonality in annual rainfall (Parrish 1993). The channel sandstone bodies bear closest similarity to the deposits of the anastomosing bedload rivers (e.g. Smith 1983; Stanistreet et al. 1993). Nanson \& Croke (1992) indicate that low stream power and strong banks are important factors in generating anastomosing channel geometries, together with rapid rates of basin subsidence (Smith 1986). These conditions would have been fulfilled during the deposition at Joggins; rates of subsidence were exceptionally high at this time (Gibling 1995) and vegetated mudstone banks may have provided adequate channel confinement.

\section{Facies 1b: meandering channels}

This facies represents the deposits of large, sandy, meandering river channels. Ridge and swale topography (RST) on the upper surface of sandstone bodies is interpreted to represent scroll bar deposits (Hickin 1974; Nanson 1980). Trough crossbedding and ripple cross-lamination in the lower part of the sandstone body, yielding southeasterly palaeocurrents parallel to the strike of the RST, records the migration of sinuouscrested megaripples and ripples downstream along the channel floor (Walker \& Cant 1984). Large cordaite tree trunks associated with the RST appear to have been stranded on the top of the point bar platform during falling stage. These may have acted as a nucleus for scroll bar formation, in a similar way to that described by Nanson (1981). Meandering river geometries may have developed at times of lower basinal subsidence when floodplain gradients relaxed (Smith et al. 1989) 


\section{Facies 1c: flood deposit}

This facies represents the deposit of an ephemeral high energy flood that scoured out broad channels and infilled them with coarse, rubbly sediment containing abundant cordaite logs and plant debris. The abundance of large (up to $10 \mathrm{~cm}$ ) mudstone, calcrete and siderite intraclasts indicates very high energy conditions. Small U-shaped sandstone ribbons incising these coarser deposits may represent small, vertically accreting channels formed during periods of lower discharge.

\section{Plant ecology of Facies 1}

The presence of dense in situ stands of Calamites in Facies $1 \mathrm{~b}$ demonstrates that these plants colonized river-channel margins. Largely unfragmented allochthonous remains of Calamites pith casts and compressions in Facies 1a and 1c also probably represent channel margin communities.

The original site of growth of the abundant cordaite remains (trunks, branches, pith-casts and leaves) is more difficult to ascertain. Actualistic studies have shown that most leaf debris in river channel deposits is derived from adjacent channel levées (Scheihing \& Pfefferkorn 1984). However, in contrast tree trunks may be transported in river channels from large distances upstream. It is known that cordaites occupied a broad spectrum of ecological niches; some species grew in mire and channel levée settings (Cridland 1964; DiMichele \& Phillips 1994) whilst others grew in extra-basinal upland environments (Chaloner 1958). The association of cordaite trunks with calcrete breccias in Facies 1 at Joggins implies that these trees may have grown in well-drained soils. This, together with the absence of cordaite trunks or in situ stumps in Facies 2-4, implies that the large cordaite trunks encountered in Facies 1 were derived from an extra-basinal community upstream rather than a lowland mire setting.

\section{Facies 2a: clastic swamps}

Green mudstone units with siderite nodules were deposited in a permanently waterlogged, reducing overbank environment. Roots indicate that these mudstone beds were colonized by lepidodendrids, calamites and pteridosperms. Gastaldo (1987) found this mixed assemblage characteristic of clastic swamps close to channel influence. Thin, laminated grey siltstone beds, associated with the green mudstone units, represent the deposits of small ponds of deeper water that periodically developed within depressions, and in which scorpions, eurypterids and bivalves lived.

\section{Facies 2b: ephemeral peat mires}

Thin coals are typical of humid anastomosing floodplain systems (Smith et al. 1989). These coals, interbedded with the green mudstone units, record periods when clastic input was low enough for peats to accumulate. Peat-forming communities were dominated by dense, mixed-age stands of sigillarian trees. Medullosan pteridosperms probably formed an understorey layer, together with subordinate calamites and cordaites. According to DiMichele \& Phillips (1994) and DiMichele et al. (1996), this assemblage is suggestive of a dry peat surface and nutrient-rich conditions. More rarely, perhaps during the driest phases, these peaty soils appear to have been occupied solely by cordaites. These ephemeral peatforming communities were overwhelmed when clastic input and flooding was renewed.

\section{Facies 2c: clastic swamps}

Red mudstone beds with siderite nodules were deposited in a water-logged overbank environment like Facies 2a. Sandstone casts of lepidodendrid trees demonstrate that, although plant material is now absent from this facies, it once supported a flora comparable to that of Facies $2 \mathrm{a}$. It is likely therefore that the red coloration and absence of organic material in Facies $2 \mathrm{c}$ is the result of syn-depositional alteration of iron-rich minerals by oxygenated pore waters (Walker 1967). Green-red fluctuations in mudstone coloration probably reflect subtle geochemical variations during deposition rather than significant changes in the physical environment.

\section{Facies 3: distributary lobes}

These heterolithic units indicate fluctuating energy conditions. The presence of ripple cross-lamination indicates generally low unidirectional currents and the burial of up to $3 \mathrm{~m}$ high lepidodendrid tree trunks implies rather high rates of sedimentation. These units may have been deposited by the progradation of distributary lobes which advanced over Sigillaria-dominated wetlands, burying upright trees (M. R. Gibling pers. comm. 1996). Centroclinal cross-stratification in this facies was generated by increased current scouring around tree trunks (Underwood \& Lambert 1974). Small channelized sandstone bodies cutting this facies may represent vertically accreting distributary channels. Standing Calamites stems and rare Stigmaria indicate that both sphenopsids and lepidodendrids colonised this environment.

\section{Facies 4: crevasse splays}

These sheet sandstone bodies represent splays of fine-grained sediment deposited on the overbank at times of channel levée failure; they buried communities of both lepidodendrids and calamites. Climbing ripples indicate rapid subsidence and high rates of deposition. The high frequency of crevasse splay deposits at Joggins is consistent with the product of anastomosing fluvial patterns (Smith et al. 1989).

\section{Fire ecology and post-fire disturbances}

The Joggins and Springhill Mines formations (Westphalian A-B) were deposited in a floodplain setting within a rapidly subsiding strike-slip basin (Gibling et al. 1992). River geometries were dominantly anastomosing and climate was seasonally humid. Three plant communities have been identified in this study. Firstly, cordaite trees grew in well-drained extra-basinal forests. Secondly, calamites formed dense stands on shifting riverside substrates. Finally, lepidodendrids and medullosan pteridosperms, together with rare cordaites and calamites, occupied floodbasin overbank niches. During drier periods this latter community was dominated by Sigillaria and medullosans, and formed thin peaty soils (Fig. 10).

\section{Charcoal Assemblage 1: extra-basinal fires}

Coniferopsid wood charcoal, probably derived from cordaite trees and early conifers, occurs commonly in channel deposits 


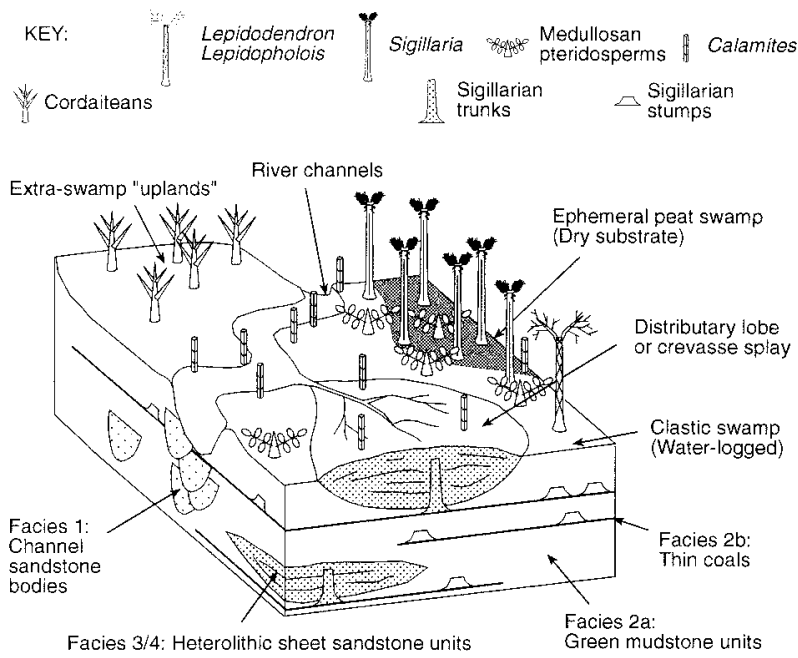

Fig. 10. Environmental and ecological interpretation of sections studied at Joggins.

at Joggins and records repeated wildfire events in extra-basinal communities. It is noted that most charcoal-bearing channel sandstone bodies at Joggins were deposited in higher energy conditions than those not containing charcoal. Such charcoalbearing channel deposits typically contain abundant mudstone intraclasts, indicating high levels of bank erosion and calcrete breccias suggestive of widespread denudation of well-drained, upstream soils. They are also poorly sorted and chaoticallybedded, indicating rapid deposition, and contain very large quantities of cordaite debris implying upstream disturbance to vegetation.

It is suggested that these unusual fluvial facies associated with charcoal may be best explained in terms of fire-related flood deposition (Swanson 1981). In the humid to seasonally humid tropics, vegetation may intercept as much as $88 \%$ of rainfall (Salati 1987). The sudden removal of substratestabilizing vegetation by fires can thus dramatically increase run-off and erosion rates, triggering debris flows which profoundly influence downstream alluvial morphology (e.g. Meyer et al. 1992; Meyer \& Wells 1997). Recent studies have identified such 'fire-flood' sequences in the Holocene of western USA (Meyer et al. 1995), and the Lower Carboniferous of Ireland (Nichols \& Jones 1992; Falcon-Lang 1998b).

The 'fire-flood' effect is particularly pronounced following fires in steepland terrains ( $>10^{\circ}$ slopes), where vegetation plays a very important role in slope stabilisation (Barro \& Conrad 1991). During the Westphalian A-B the nearest steeplands upstream of Joggins were the Caledonia Highlands, $22 \mathrm{~km}$ to the northeast (Gibling et al. 1992), and the uplands of the Minudie Anticline, $8 \mathrm{~km}$ to the north (Calder 1994). Although fire-related debris flows generally do not affect areas more than $1 \mathrm{~km}$ from burnt slopes (Meyer \& Wells 1997), dilute sediment-lain floods extend much further beyond this range. Unfortunately, no quantitative data exists concerning the sedimentological effects of wildfire on fluvial reaches more than $4 \mathrm{~km}$ downstream of burnt slopes. It is well documented, however, that even small fires (e.g. 0.01 ha) can increase their catchments' run-off by nine-fold, and sediment discharge by 200-fold, 1-2 km downstream (Wells 1981). Therefore it is quite likely that moderate to large forest fires could strongly influence alluvial morphology up to $22 \mathrm{~km}$ downstream, the distance from the Westphalian Caledonia Highlands to the Joggins Basin.
Charcoal-bearing channel deposits at Joggins were formed by high-energy, dilute flows consistent with the expected distal effects of a fire-flood sequence. If we accept that these chaotic channel deposits bearing cordaite trunks and charcoal represent fire-flood sequences, and that this phenomenon is mainly initiated in burnt steepland terrains, then this lends further weight to the notion that the large monopodial cordaites found in the channel facies at Joggins occupied extra-basinal upland niches.

\section{Charcoal Assemblage 2: distal overbank fires}

Wildfire in an entirely different plant community is indicated by charcoal found within the thin coals of Facies $2 b$. Here, the occurrence of in situ sigillarian stumps associated with charred sigillarian periderm represents autochthonous sigillarian forest fire profiles.

Sigillarian trees were composed structurally of a central woody stele and a peripheral parenchymous cortex surrounded by a thick, woody periderm (Eggert 1961). The presence of a charcoal mat often found at the base of the stumps at Joggins is important. The charcoal within this mat has evidently only been transported a very short distance as there is a complete lack of interstitial clastic sediment. One possible explanation for the existence of the charcoal mat is that, as the tree burned, flames tunnelled out the parenchymous core of the tree and charred the outer periderm. Following the fire, charcoal then progressively fell off the remaining charred periderm cylinder into the hollow trunk base and formed the charcoal mat. Two strands of evidence support this interpretation. Firstly, the structure of the charcoal mat, composed of a basal parenchymous layer overlain by a periderm-dominated layer, is exactly the relationship one would expect if the parenchymous core of the trunk had first been burned out and then charred fragments from the remaining periderm cylinder had fallen in. Secondly, the progressively less charred nature of fragments up through the mat is consistent with material falling off a hollow, internally charred trunk over time. Had these fragments settled out in water, the opposite trend would have been observed, with material becoming less charred downwards (because charcoal settles more slowly than uncharred material; Vaughan \& Nichols 1995).

Periderm charcoal scattered around the stumps to a distance of up to 1-3 m may give an indication of the radius of the crown of Sigillaria. The rarity of charred sigillarian foliage in the thin coals is to be expected as foliage is 10-20 times more likely to be converted to soluble ashes than is woody tissue (Kuhlbusch \& Crutzen 1995). Indeed, the presence of a calcite layer associated with the charcoal layers in this facies may represent the product of such soluble ashes (DeBano et al. 1979). Distinct rhythmic banding within the charred sigillarian periderm may suggest that these trees experienced periodic water stress (Wnuk 1985). Periodic droughts, perhaps related to climatic seasonality (Calder \& Gibling 1994), may then have been the primary trigger of wildfire.

Medullosan charcoal, within the thin coals, together with rare charred fragments of Cordaites, sphenopsid leaves and coniferopsid wood, indicate that the pteridosperm-dominated understory also burned. However, as the sigillarian stumps of Facies $2 \mathrm{~b}$ are not charred, these fires were predominantly aerial and never heated the forest floor very much. This charcoal data from Facies $2 \mathrm{~b}$ is in good agreement with charcoal analysis in coals elsewhere (DiMichele et al. 1985, 1996; 


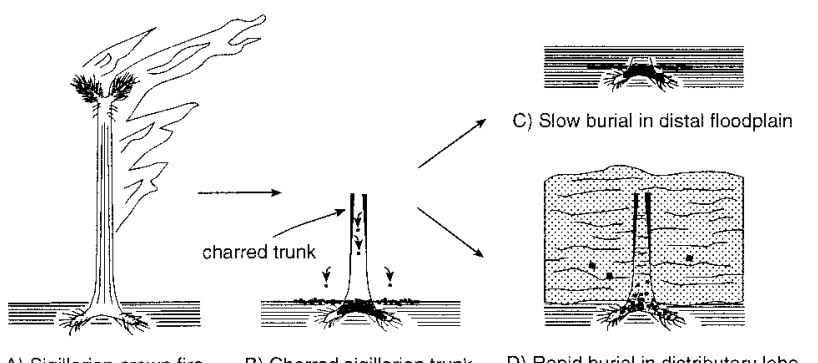

$\begin{array}{llll}\text { A) Sigillarian crown fire } & \text { B) Charred sigillarian trunk } & \text { D) Rapid burial in distributary lobe }\end{array}$

Fig. 11. Summary diagram showing how Charcoal Assemblages 2 and 3, associated with Sigillaria were produced.

DiMichele \& Phillips 1988, 1994). These authors also suggest that medullosans were the most fire-prone plant community within Carboniferous coal mire systems, and that architectural features such as thick cuticles and resin canals may have been fire adaptations. Sigillarian-medullosan forest fire profiles at Joggins were preserved in slowly, vertically accreting overbank muds so that only the basal stumps of Sigillaria survived (Fig. 11a-c).

Finally, it is noted that charcoal is absent in the diagenetically altered (oxidized) red mudstone units of Facies $2 \mathrm{c}$. These were formed under a similar vegetation cover to the charcoalbearing green mudstone units. At Joggins, red mudstone units are about twice as abundant as the green mudstone units, yet the latter contain 26 charcoal horizons. Shneour (1966) has demonstrated that charcoal breaks down slowly in soils under oxidizing conditions. The absence of charcoal in the red beds (Facies 2c) may then imply that the charcoal has been oxidized away from these units.

\section{Charcoal Assemblage 3: proximal overbank fires}

A charred, $2 \mathrm{~m}$ high sigillarian trunk preserved in a distributary lobe sandstone at Joggins (Fig. 9) represents the same fire-prone community as identified in Assemblage 2. However, whereas those sigillarians were buried slowly and preserved only as stumps in Facies 3, where sedimentation rates were much higher, a nearly complete charred tree has survived (Fig. $11 \mathrm{a}, \mathrm{b}, \mathrm{d})$. In this example, the bark rind is charred both on the outside and inside above a height of $1.5 \mathrm{~m}$ over the palaeosol. This observation is again suggestive that the parenchymous core of sigillarian trees was tunnelled out by flames during wildfire events. The charred layer is thinnest on the outside of the trunk, most of it probably having been removed by the abrasive effects of wind or water.

Grey siltstone bearing a mixture of charred and partially charred periderm at the base of this trunk is interpreted as being the distorted remains of a charcoal mat, originally similar to those described in Assemblage 2. It is suggested that this charcoal bed was formed when sediment from the advancing distributary lobe overtopped the hollow, charred tree trunk rim and mixed up the basal charcoal mat and an overlying layer of unconsolidated mud. In Assemblage 3, charcoal is not found scattered around the outside of the trunk as in Assemblage 2. However, in this example the base of the distributary lobe was slightly erosive and it is therefore likely that this charcoal has been washed away. To support this suggestion, large $(1-2 \mathrm{~cm})$, isolated blocks of sigillarian periderm are sometimes encountered both in lobe and crevasse splay deposits (Facies 3 and 4) not associated with lepidodendrid trees.
Finally, fragments of coniferopsid wood found in Facies 3 and 4 were probably derived from the same extra-basinal, fire-prone community as established for Assemblage 1. This charcoal was probably initially transported in river channels (Facies 1) but was subsequently distributed out onto the overbank within crevasse splays and distributary lobes.

\section{Tetrapod remains}

Several previous studies have also found chaotic charcoalbearing mudstone beds in the base of upright lepidodendrid trunks (Assemblage 3) at Joggins (Lyell \& Dawson 1853; Dawson 1860, 1868). Significantly, the skeletons of more than 100 tetrapods (both reptiles and amphibians) have been encountered, exclusively associated with these basal trunk deposits (Carroll 1964; Scott \& Calder 1994). Single trees have occasionally yielded several distinct taxa of tetrapod, together with numerous coprolites. Naturally, the origin of these remarkable tetrapod-charcoal deposits has been the source of very considerable debate over the last century (Scott 1998). One explanation might be that the animals of these Carboniferous forests sought protection in the partially hollow bases of lepidodendrid trunks during wildfires and suffocated where they sheltered. Wildfire has also been implicated in the formation of Permian (Sander 1987) and Lower Carboniferous (Rolfe et al. 1990; Falcon-Lang 1998b) vertebrate fossil accumulations.

\section{Conclusions}

(1) Examination of the facies distribution and botanical identity of charcoal has revealed the presence of two fire-prone plant communities in the Late Carboniferous (Westphalian A-B) floodplain sediments of Joggins, Nova Scotia.

(2) Charcoal in river channel deposits (Facies 1) indicates that a first 'fire-prone community' consisted of cordaite/conifer forests composed of large individuals with trunk diameters up to $50 \mathrm{~cm}$. This community occupied a dry, extra-basinal, upland niche, and wildfires in this setting led to the destabilisation of upland slopes. Greatly enhanced levels of erosion and runoff followed fires and caused flooding in the downstream floodplain system.

(3) Charcoal associated with lepidodendrid tree trunks and stumps, preserved in overbank peat-forming environments (Facies 2b) and distributary lobe deposits (Facies 3), indicates that a second 'fire-prone community', this time mire-based, was dominated by Sigillaria and medullosan pteridosperms. Detailed studies of this charcoal have revealed that as Sigillaria burnt, charcoal accumulated within the central hollow of its trunk as a dense charcoal mat. Abundant tetrapod remains, found within the bases of burnt trees, may indicate that these animals were killed during fire events.

I thank M. R. Gibling, J. H. Calder and their families for friendship, encouragement and generous field support whilst working in Nova Scotia. This paper has greatly benefited from discussions with W. G. Chaloner, G. J. Nichols and A. C. Scott, and from insightful reviews by W. A. DiMichele and J. E. Francis. I acknowledge the receipt of a RHUL studentship and Research Committee funding to cover fieldwork costs.

\section{References}

Archer, A.W., Calder, J.H., Gibling, M.R., Naylor, R.D., Reid, D.R. \& Wightman, W.G. 1995. Invertebrate trace fossils and agglutinated 
foraminifera as indicators of marine influence with the classic Carboniferous section at Joggins, Nova Scotia, Canada. Canadian Journal of Earth Sciences, 32, 2027-2039.

Barro, S.C. \& Conrad, S.G. 1991. Fire effects on Californian chaparral systems: an overview. Environment International, 17, 135-149.

Browne, F.L. 1958. Theories on the combustion of wood and its control. USDA Forest Production Laboratory Report No. 2136.

CALDER, J.H. 1994. The impact of climate change, tectonism and hydrology on the formation of Carboniferous tropical intermontane mires: the Springhill coalfield, Cumberland Basin, Nova Scotia. Palaeogeography, Palaeoclimatology, Palaeoecology, 106, 323-351.

— \& Gibling, M.R. 1994. The Euramerican Coal Province: controls on Late Palaeozoic peat accumulation. Palaeogeography, Palaeoclimatology, Palaeoecology, 106, 1-21.

Carroll, R.L. 1964. The earliest reptiles. Journal of the Linnean Society (Zoology), 45, 61-83.

Chaloner, W.G. 1958. The Carboniferous upland flora. Geological Magazine, 95, 261-262.

Cridland, A.A. 1964. Ameylon in American coal balls. Palaeontology, 7, 186-209.

CyPERT, E. 1972. Plant succession on the burned areas in Okefenokee Swamp following the fires of 1954 and 1955. In: Proceedings of the Annual Tall Timbers Fire Ecology Conference, 12, 199-217.

DAwson, J.W. 1860. On a terrestrial mollusk, a chilognathous myriapod, and some new species of reptiles from the coal formation of Nova Scotia. Quarterly Journal of the Geological Society of London, 16, 268-277.

1868. Acadian Geology. Macmillan \& Co., London.

DeBano, L.F., Rice, R.M. \& Conrad, C.E. 1979. Soil heating in chaparral fires: effects on soil properties, plant nutrients, erosion and runoff. Pacific SW Forest and Range Experimental Station, Forest Service, USDA Research Paper PSW-145.

DiMichele, W.A. \& Phillips, T.L. 1988. Palaeoecology of the middle Pennsylvanian-age Herrin coal swamp (Illinois) near a contemporaneous river system, the Walshville Palaeochannel. Review of Palaeobotany and Palynology, 56, 151-176.

_ \& 1994. Palaeobotanical and palaeoecological constraints on models of peat formation in the Late Carboniferous of Euramerica. Palaeogeography, Palaeoclimatology, Palaeoecology, 106, 39-90.

- Pfefferkorn, H.W. \& Phillips, T.L. 1996. Persistence of Late Carboniferous tropical vegetation during glacially-driven climatic and sea-level fluctuations. Palaeogeography, Palaeoclimatology, Palaeoecology, 125, 105 128.

- Phillips, T.L. \& Peppers, R.A. 1985. The influence of climate and depositional environment on the distribution and evolution of Pennsylvanian coal-swamp plants. In: Tiffney, B.H. (ed.) Geological factors and the evolution of plants. Yale University Press, New Haven, London, 223-256.

EGgert, D.A. 1961. The ontogeny of Carboniferous arborescent Lycopsida Palaeontographica B, 108, 43-92.

FalCON-LANG, H.J. 1998a. Carboniferous Wildfires: Their impact on vegetation, ecology and depositional environments. PhD thesis, University of London, UK.

1998b. The impact of wildfire on an Early Carboniferous coastal system, North Mayo, Ireland. Palaeogeography, Palaeoclimatology, Palaeoecology, 139, 121-138.

Friend, P.F., Hirst, J.P.P. \& Nichols, G.J. 1986. Sandstone-body structure and river process in the Ebro Basin of Aragon, Spain. Cuadernos Geologia Ibérica, 10, 9-30.

—, Slater, M.J. \& Williams, R.C. 1979. Vertical and lateral building of river sandstone bodies, Ebro Basin, Spain. Journal of the Geological Society, London, 136, 39-46.

Galtier, J., Scott, A.C., Powell, J.H., Glover, B.W. \& Waters, C.N. 1992. Anatomically preserved conifer-like stems from the Upper Carboniferous of England. Proceeding of the Royal Society of London, B, 247, 211-214.

Gastaldo, R.A. 1987. Confirmation of Carboniferous clastic swamp communities. Nature, 326, 869-871.

Gibling, M.R. 1987. A classic Carboniferous section; Joggins, Nova Scotia. In: Geological Society of America. Centennial Field Guide-NE section, 409-414.

- 1995. Upper Palaeozoic rocks, Nova Scotia. In: Williams, H. (ed.) Geology of the Appalachian-Caledonian Orogen of Canada and Greenland. Geological Survey of Canada, Geology of Canada, 6, 493-523.

— Calder, J.H., Ryan, R., Van de Poll, H.W. \& Yeo, G.M. 1992. Late Carboniferous and Early Permian drainage patterns in Atlantic Canada. Canadian Journal of Earth Sciences, 29, 338-352.
Goldammer, J.G. 1993. Historical biogeography of fire: Tropical and subtropical. In: Crutzen, P.J. \& Goldammer, J.G. (eds) Fire in the environment: The ecological, atmospheric and climatic importance of vegetation fires. John Wiley \& Sons, 297-314.

— \& Seibert, B. 1990. The impact of droughts and forest fires on tropical lowland rain forest of East Kalimantan. In: Goldammer, J.G. (ed.) Fire in the tropical biota: Ecosystem processes and global challenges. SpringerVerlag, Berlin, 11-31.

Good, C.W. \& TAYlor, T.N. 1970. On the structure of Cordaites felicis Benson from the Lower Pennsylvanian of North America. Palaeontology, 13, 29-39.

Goudie, A.S. 1983. Calcrete. In: Goudie, A.S. \& Pye, K. (eds) Chemical sediments and geomorphology. Academic Press, London, 93-131.

Hickin, E.J. 1974. The development of meanders in natural river channels. American Journal of Science, 274, $414-442$.

Johnson, B. 1984. The Great Fire of Borneo: Report of a Visit to KalimantanTimur a Year Later, May 1984. World Wild-Life Fund, Godalming, Surrey.

Jones, T.P. \& Chaloner, W.G. 1991. Fossil charcoal, its recognition and palaeoatmospheric significance. Palaeogeography, Palaeoclimatology, Palaeoecology (Global Planetary Change Section), 97, 39-50.

_ ScotT, A.C. \& Cope, M.J. 1991. Reflectance measurements and the temperature of formation of modern charcoals and implications for studies of fusain. Bulletin de la Société géologique de France, 162, 193-200.

Kunlbusch, T.A. \& Crutzen, P.J. 1995. Towards a global estimate of black carbon in residues of vegetation fires representing a sink of atmospheric $\mathrm{CO}_{2}$ and a source of $\mathrm{O}_{2}$. Global Biogeochemical Cycles, 9, 491-501.

Lyell, C. \& Dawson, J.W. 1853. On the remains of a reptile (Dendrerpeton acadianum, Wyman and Owen) and of a land snail discovered in the interior of an erect fossil tree in the coal measures of Nova Scotia. Quarterly Journal of the Geological Society of London, 9, 59-63.

Meyer, G.A. \& Wells, S.G. 1997. Fire-related sedimentation events on alluvial fans, Yellowstone National Park, USA. Journal of Sedimentary Research, 67, 776-791.

———, Balling, R.C. \& Timothy Jull, A.T. 1992. Response of alluvial systems to fire and climate change in Yellowstone National Park. Nature, 357, 147-150.

— \& Timothy Jull, A.T. 1995. Fire and alluvial chronology in Yellowstone National Park: climatic and intrinsic controls on Holocene geomorphic processes. Geological Society of America Bulletin, 107, 12111230 .

NAnson, G.C. 1980. Point bar and floodplain formation of the meandering Beatton River, northeastern British Columbia, Canada. Sedimentology, 27, 3-29.

1981. New evidence of scroll-bar formation on the Beatton River. Sedimentology, 28, 889-891.

\& CROKe, J.C. 1992. A genetic classification of floodplains. Geomorphology, 4, 459-486.

NichoLs, G.J. \& Jones, T.P. 1992. Fusain in Carboniferous shallow marine sediments, Donegal, Ireland: the sedimentological effects of wildfire. Sedimentology, 39, 487-502.

PARrish, J.T. 1993. The climate of the supercontinent of Pangea. Journal of Geology, 101, 215-233.

Robinson, J.M., Chaloner, W.G. \& Jones, T.P. 1997. Pre-Quaternary records of wildfire. In: Clark, J.S., Cachier, H., Goldammer, J.G. \& Stocks, B. (eds) Sediment records of biomass burning and global change. NATO ASI Series, I51. Springer-Verlag, Berlin, 253-270.

Rolfe, W.D.I., Durant, G.P., Fallick, A.E., Hall, A.J., Large, D.J., Scott, A.C., Smithson, T.R. \& Walkden, G.M. 1990. An early terrestrial biota preserved by Visean volcanicity in Scotland. In: Lockley, M.G. \& Rice A. (eds) Volcanism and Fossil biotas. Geological Society of America Special Publications, 244, 13-24.

Rust, B.R., Gibling, M.R. \& Legun, A.S. 1984. Coal deposition in an anastomosing-fluvial system: the Pennsylvanian Cumberland Group south of Joggins, Nova Scotia, Canada. In: Rahman, R.A. \& Flores, R.M. (eds) Sedimentology of Coal and Coal-bearing Sequences. International Association of Sedimentologists Special Publications, 7, 105-120.

Ryan, R.J. \& Boehner, R.C. 1993. Geology of the Cumberland Basin, Cumberland, Colchester and Pictou Counties, Nova Scotia. In: Nova Scotia Department of Natural Resources Mines and Energy Branch Memoirs, 10, 28.

Salati, E. 1987. The forest and the hydrological cycle. In: Dickinson, R. E. (ed.) The geophysiology of Amazonia. Wiley \& Sons, New York, 273-296.

SANDER, P.M. 1987. Taphonomy of the Lower Permian Geraldine bonebed in Archer County, Texas. Palaeogeography, Palaeoclimatology, Palaeoecology, 61, 221-236. 
Scheining, M.H. \& Pfefferkorn, H.W. 1984. The taphonomy of land plants in the Orinoco Delta: a model for the incorporation of plant-parts in clastic sediments of Late Carboniferous age of Euramerica. Review of Palaeobotany and Palynology, 41, 205-240.

SCOTESE, C.R. \& MCKerRow, W.S. 1990. Revised world maps and introduction. In: McKerrow, W.S. \& Scotese, C.R. (eds) Palaeozoic Palaeogeography and Biogeography. Geological Society, London, Memoirs, 12, 1-21.

ScotT, A.C. 1979. The ecology of Coal Measure floras from northern Britain. Proceedings of the Geologists' Association, 90, 97-116.

- 1989. Observations on the nature and origin of fusain. International Journal of Coal Geology, 12, 443-475.

- 1998. The legacy of Charles Lyell: advances in our knowledge of coal and coal-bearing strata. In: ScotT, A.C. \& Blundell, D.W. (eds) Lyell: the Past is the Key to the Present. Geological Society, London, Special Publications, 43, 243-260.

\& Calder, J.H. 1994. Carboniferous fossil forests. Geology Today, 10, 213-217.

— \& JonES, T.P. 1994. The nature and influence of fire in Carboniferous ecosystems. Palaeogeography, Palaeoclimatology, Palaeoecology, 106, 91112.

SHNeOUR, E. 1966. Oxidation of graphitic carbon in certain soils. Science, 151, 991-992.

Smith, D.G. 1983. Anastomosed fluvial deposits: examples from alluvial valleys near Banff, Alberta. Journal of Sedimentary Petrology, 50, 157-164.

1986. Anastomosing river deposits, sedimentation rates and basin subsidence, Magdalena River, northwestern Columbia, South America. Sedimentary Geology, 46, 177-196.

Smith, N.D., Cross, T.A., Dufficy, J.P. \& Clough, S.R. 1989. Anatomy of an avulsion. Sedimentology, 36, 1-23.

Stanistreet, I.G., Cairncross, B. \& McCarthy, T.S. 1993. Low sinuosity and meandering bedload rivers of the Okavango Fan: channel confinement by vegetated levees without fine sediment. Sedimentary Geology, 85, 135156.

Stankiewicz, B.A., Scott, A.C., Collinson, M.E., Finch, P., Mosle, B., Briggs, D.E.G. \& Evershed, R.P. 1998. Molecular taphonomy of arthropod and plant cuticles from the Carboniferous of North America: implications for the origin of organic matter in kerogen. Journal of the Geological Society, London, 155, 453-462.

Staub, J.R. \& Cohen, A.D. 1979. The Snuggedy Swamp of South Carolina: a back-barrier estuarine coal-forming environment. Journal of Sedimentary Petrology, 49, 133-144.

Swanson, F.J. 1981. Fire and geomorphic processes. In: Mooney, H.A. Bonnicksen, T.H., Christensen, N.L., Lotan, J.E. \& Reiners, W.A. (eds) Fire Regimes and Ecosystem Properties. USDA Forest Service, General Technical Report WO-26, 401-420.

Underwood, J.R. \& LAMBERT, W. 1974. Centroclinal cross strata, a distinctive sedimentary structure. Journal of Sedimentary Petrology, 44, 1111-1113.

Vaughan, A. \& Nichols, G.J. 1995. Controls on the deposition of charcoal: implications for sedimentary accumulation of charcoal. Journal of Sedimentary Research, A65, 129-135.

Walker, R.G. \& Cant, D.J. 1984. Sandy fluvial systems. In: Walker, R.G. (ed.) Facies Models. Geoscience Canada, Reprint Series, 1. Geological Society of Canada, Waterloo, 71-91.

WALKER, T.R. 1967. Formation of red beds in modern and ancient deserts. Bulletin of the Geological Society of America, 78, 353-368.

Wells, W.G. 1981. Some effects of brushfires on erosion in coastal Southern California. In: Davies, T.R.H. \& PeArce, A.J. (eds) Erosion and sediment transport in Pacific Rim steeplands. International Association of Hydrological Sciences, Publication No. 132

WNUK, C. 1985. The ontogeny and palaeoecology of Lepidodendron rinosum and Lepidodendron bretonense trees from the middle Pennsylvanian of the Bernice Basin (Sullivan County, Pennsylvania). Palaeontographica B, 195, $153-181$. 